\title{
Karl Fischer Water Titration-Principal Component Analysis Approach on Bread Products
}

\author{
Gabriela Popescu ${ }^{1}$, Isidora Radulov ${ }^{2}$, Olimpia A. Iordănescu ${ }^{3}$, Manuela D. Orboi ${ }^{4}$, \\ Laura Rădulescu ${ }^{5}$, Mărioara Drugă ${ }^{6}$, Gabriel S. Bujancă ${ }^{5}$, Ioan David ${ }^{6}$, Daniel I. Hădărugă ${ }^{7}$,
} Christine A. Lucan (Banciu) ${ }^{6}$, Nicoleta G. Hădărugă ${ }^{6, *(1)}$ and Mircea Rivişs ${ }^{8}(\mathbb{0}$

1 Department of Management and Rural Development, Banat's University of Agricultural Sciences and Veterinary Medicine "King Michael I of Romania" from Timişoara, Calea Aradului 119, 300645 Timişoara, Romania; gabrielapopescu@usab-tm.ro

2 Department of Soil Sciences, Banat's University of Agricultural Sciences and Veterinary Medicine "King Michael I of Romania" from Timişoara, Calea Aradului 119, 300645 Timişoara, Romania; isidora_radulov@usab-tm.ro

3 Department of Horticulture, Banat's University of Agricultural Sciences and Veterinary Medicine "King Michael I of Romania" from Timişoara, Calea Aradului 119, 300645 Timişoara, Romania; olimpiaiordanescu@usab-tm.ro

4 Department of Economics and Company Financing, Banat's University of Agricultural Sciences and Veterinary Medicine “King Michael I of Romania" from Timişoara, Calea Aradului 119, 300645 Timişoara, Romania; orboi@usab-tm.ro

5 Department of Food Control and Expertise, Banat's University of Agricultural Sciences and Veterinary Medicine "King Michael I of Romania" from Timişoara, Calea Aradului 119, 300645 Timişoara, Romania; laura.radulescu@usab-tm.ro (L.R.); gabrielbujanca@usab-tm.ro (G.S.B.)

6 Department of Food Science, Banat's University of Agricultural Sciences and Veterinary Medicine "King Michael I of Romania" from Timişoara, Calea Aradului 119, 300645 Timişoara, Romania; marioaradruga@usab-tm.ro (M.D.); ioandavid@usab-tm.ro (I.D.); alexalukan@gmail.com (C.A.L.)

7 Department of Applied Chemistry, Organic and Natural Compounds Engineering, Polytechnic University of Timişoara, Carol Telbisz 6, 300001 Timişoara, Romania; daniel.hadaruga@upt.ro

8 Department of Dental Medicine, "Victor Babeş" University of Medicine and Pharmacy Timişoara, Eftimie Murgu Sq. 2, 300041 Timişoara, Romania; rivis.mircea@umft.ro

* Correspondence: nicoletahadaruga@usab-tm.ro; Tel.: +40-256-277-423

Received: 18 August 2020; Accepted: 14 September 2020; Published: 18 September 2020

Featured Application: Classification of bread products as a specific type of food product according to a standard database, using coupled Karl Fischer titration and multivariate analysis

Abstract: (1) Background: The water content and the way of bonding in the food matrices, including bread, can be easily and simply evaluated by Karl Fischer titration (KFT). The goal was to identify the main KFT parameters that influence the similarity/dissimilarity of commercial bread products, using multivariate statistical analysis. (2) Methods: Various commercial bread samples were analyzed by volumetric KFT and the water content, parameters from titration process and KFT kinetics were used as input for principal component analysis (PCA). (3) Results: The KFT water content was in the range of $35.1-44.2 \%$ for core samples and $19.4-22.9 \%$ for shell samples. The storage and transportation conditions consistently influence the water content of bread. The type of water molecules can be evaluated by means of KFT water reaction rates. The mean water reaction rates up to $2 \mathrm{~min}$ are consistently higher for bread core samples, which indicates a high fraction of "surface" water. PCA reveals the similarity of core samples and various bread types, as well as dissimilarity between bread parts, mainly based on KFT kinetic parameters. (4) Conclusions: KFT kinetics can be a useful tool for a rapid and simple differentiations between various types of bread products. 
Keywords: bread; water content; Karl Fischer titration; KFT kinetics; principal component analysis

\section{Introduction}

Bread is one of the most consumed food products all over the world. There are various types of bread from the main ingredients and shapes points of view. Wheat bread is largely commercialized, made even by wheat flour or mixed with other cereal flour types such as rye [1,2]. On the other hand, rye bread has become more popular, as has whole grain bread [3,4]. Other bread types are "special" or "functional" food products $[2,5,6]$. Generally, white bread is made by common wheat flour (Triticum aestivum L. var. aestivum), water, yeast, shortening agents, sugar and salt. Nutritional and organoleptic characteristics can be enhanced by addition of oils and fats, oilseeds, almonds or legumes. On the other hand, gluten-free or low carbohydrate products can be obtained using rice, corn or cassava flour. Depending on the desired characteristics of the final products, additives such as enzymes, emulsifiers, gums modified starch or cellulose, as well as protein-rich ingredients (egg and soy), can be used [1,7-18].

The composition of bread strongly influences its final properties, such as nutritional value, taste and flavor, rheological properties and shelf-life $[4,19]$. In this regard, water plays an important role, in both dough and bread processing steps $[20,21]$. Water molecules can migrate between starch and gluten [22]. During these steps, starch gelatinizes and water can partially evaporate from the bread surface [23-25]. Water molecules migrate from the core to the surface, but the diffusive flow of liquid water is slower than the evaporation process. On the other hand, the partial water vaporization in the bread provide a vapor pressure gradient. Water vapor migrates to the core and condensates (mechanism of "evaporation-condensation") [26]. Consequently, the outer zone of the bread starts drying and forms the crust. These variations on water content and distribution influence the final properties of bread such as softness of the crumb or the crispness of the crust [26]. Among starch and gluten, which can range $45-58 \%$ in bread, proteins $(\sim 6 \%)$ also influence the water content and mobility $[6,20]$.

It is a challenge to determine the water content, water molecule types and their mobility in such complex food matrices. There are many methods of water determinations including physical or chemical methods [27]. Many factors influence the results, such as limit of detection, type of water, compounds that bias the measurement method or sample solubility and diffusion of all water molecules. Physical methods are based on weight loss, such as oven, infrared and microwave drying or thermogravimetry, as well as spectral and other physical properties of the sample (e.g., conductimetry, refractive index or capacity) [28-33]. The water determination in bread is generally based on such methods. Other methods are based on chemical properties of samples. It is the case of Karl Fischer water titration (KFT, volumetric or coulometric techniques) and other types of titration methods (acyl halide, anhydride and calcium carbide). Moreover, water distribution between dough components, water hydration capacity or other properties can be evaluated by farinograph method $[22,34]$.

KFT is a useful method for water determination in various materials, including less soluble or insoluble samples. The water content can be easily and selectively determined in complex food matrices such as dairy and meat products, honey, sugars, chocolate, fruits and vegetables, spices and cereal products $[3,35-39]$. There are many advantages for water determination by KFT: cover all water content ranges (ppm to $100 \%$, by selecting coulometric, single- or bi-component volumetric techniques), determination of both free and "strongly retained" water, a wide range of solvent polarity and temperature of analysis, which allows protecting less stable/degradable samples, rapid and simple technique and equipment, increased sensitivity and accuracy and possibility of coupling with other equipment such as oven or distillation apparatus [38-40]. On the other hand, some compounds can interfere with the KFT reagents (such as aldehydes and ketones, which react with the alcohol used as solvent, or compounds that react with iodine-reducing agents) $[27,31,33]$. 
The KFT working parameters can be selected according to the composition and characteristics of the food sample. If the food product has a high content of oil and/or fat and lower content of water, the coulometric KFT technique can be used. On the other hand, these types of food products having higher content of water, such as in the case of butter, require volumetric KFT working with more hydrophobic solvent mixtures (e.g., methanol-decanol). The electrode coating for lecithin-based samples can be prevented by adding chloroform and formamide. Soybean, rapeseed, sunflower, sesame and pumpkin seed oils have been analyzed by coulometric KFT. The water content was in the range of $0.098-0.689 \%$ by automated coulometric KFT and $0.079-0.684 \%$ for manual KFT [38]. On the contrary, butter oil had $0.061-0.108 \%$ and $0.079-0.099 \%$ water by volumetric KFT working in methanol/chloroform and methanol/hexanol solvent mixtures, respectively [41].

Cereals, cereal-based products, sugars and dairy food ingredients and products have been widely studied from the KFT water content point of view. They generally have higher water content. On the other hand, the highly hydrophilic components (carbohydrates such as starch, mono- and disaccharides such as sucrose and lactose and proteins such as gluten) strongly interact with water molecules. Such components are less soluble in the KFT working medium and the extraction of water from the sample particles are enhanced by increasing the temperature analysis, using the homogenization or milling, and increasing the solvent polarity by adding polar solvents (e.g., formamide). Water content of wheat and rye flour mixtures have been determined using volumetric KFT at elevated temperature [3,12], while for sorghum the KFT water content at $65{ }^{\circ} \mathrm{C}$ slowly decreased from $12.9 \%$ to $12.25 \%$ by increasing the grinding time from 10 to $90 \mathrm{~s}$ [39]. Other studies used starch, chick-pea flour, dry alimentary small paste or toasted ground barley for the determination of water content by volumetric KFT. For a better accuracy, the determination temperature was increased to $50^{\circ} \mathrm{C}$, where the water content was up to $0.7 \%$ higher than for the analysis temperature of $25^{\circ} \mathrm{C}$ [42]. Invert sugar and fructose syrups have been compared for their water content and the corresponding mass loss at elevated temperature. They have a water content of $26.67 \%$ and $29.46 \%$ for invert sugar and fructose syrups, respectively. On the other hand, the mass loss was in the range of $26.4-26.7 \%$ for inverted sugar syrup dried at $105^{\circ} \mathrm{C}$, while for fructose syrup the mass loss had no significant variation by halogen drying at $100-115^{\circ} \mathrm{C}$ (mass loss of 29.06-29.46\%) [32]. Similar observations were accounted for maltose (5.1-5.64\% KFT water content or halogen drying mass loss), glucose monohydrate ( $8.34 \%$ by KFT and $7.72 \%$ mass loss), sucrose $(0.024 \%$ by KFT and $0.055-0.062 \%$ mass loss) or isomalt- and sorbitol-based candies [30]. All determinations required elevated temperature $\left(50^{\circ} \mathrm{C}\right)$, formamide addition and internal homogenization. Sucrose I and II and fructose had the KFT water content of $0.0552-0.0556 \%, 0.0464-0.0469 \%$ and $0.0800-0.0803 \%$, respectively, while for glucose monohydrate the determined water content was consistently higher (8.84\%). $\alpha$-Lactose (lactose monohydrate), anhydrous $\beta$-lactose and the amorphous form have different water content, which is difficult to determine. Volumetric KFT performed in fifteen laboratories at $40^{\circ} \mathrm{C}$ provide relatively close results for water content of various commercial lactose ranging $4.48-5.19 \%$ [43]. A comprehensive study on the use of vaporization coulometric KFT technique have been performed by Kestens and co-workers [44]. The robustness and good repeatability of this coupled technique was demonstrated for various difficult food matrices, including toasted bread.

Dairy products and protein-containing food products have high content of water. Generally, proteins are more hydrophilic and formamide can be added in order to enhance the water extraction during volumetric KFT analysis [27]. Moreover, homogenization and enhancing analysis temperature can be applied (for example, for meat products) $[35,45,46]$. On the other hand, high fat dairy products need the addition of more hydrophobic solvents to the KFT working medium (such as chloroform or decanol). Isengard and collaborators [29] also used 1-propanol, 1-butanol or tert-butyl-methyl-ether in order to enhance the water extraction in the volumetric KFT analysis at $50^{\circ} \mathrm{C}$ for water determination in dried milk products. When the gas extraction was coupled with an automated KFT technique, using methanol-octanol solvent mixture at $40{ }^{\circ} \mathrm{C}$, valuable results for the water content of various commercial butter samples have been obtained [40]. Products having high content of fats and sugars need homogenization and cooling, as well as hydrophilic or more hydrophobic solvent mixture, 
depending of the characteristic of the main components-sugars and fats, respectively. Instant powders such as coffee substitutes, coffee and cocoa-based instant powders have been analyzed by volumetric KFT by addition of formamide [47].

The goal of the present study was to identify the main KFT parameters that influence the similarity/dissimilarity between commercial bread products, using multivariate statistical analysis-principal component analysis (PCA)—as a useful combined tool for a rapid and simple differentiations between various types of bread products.

\section{Materials and Methods}

\subsection{Materials}

Bread samples were obtained from the local market (the flour used for obtaining the bread products by various local producers was from the same manufacturer, Timişoara, Timiş county, Romania). Three major groups of bread samples were used for KFT and multivariate PCA analyses: (1) White wheat breads consisted of five sample types, which varied only in the shape and presence or absence of different seeds on the top of the bread (these extra-materials were not included in samples for analysis): "HC1", white wheat bread, non-packed (core); "HC2", white wheat bread, sliced and packed in plastic bag (core); "HC3", white wheat bread roll, non-packed (core); "HC4", white wheat bread roll, topped with various seeds, non-packed (core); and "HC5", homemade white wheat bread (core). A Moulinex OW 3022 Home Bread, having kneading (5, 20, 0.2 and $0.25 \mathrm{~min}$, alternately with rests or growing), rest (5 min after the first kneading), growing (39, 25.5 and $49.45 \mathrm{~min}$ after the second to fourth kneading), baking (48 $\mathrm{min}$, followed by $2.51 \mathrm{~min}$ ), and maintaining at warm condition ( $60 \mathrm{~min}$ ) cycles, was used. The homemade white wheat bread was obtained from $455 \mathrm{~g}$ of white wheat flour (from the same manufacturer as above), $250 \mathrm{~mL}$ of water, $30 \mathrm{~g}$ of sugar, $8 \mathrm{~g}$ of salt, $26 \mathrm{~g}$ of milk powder, $25 \mathrm{~g}$ of sunflower oil and $9 \mathrm{~g}$ of yeast. (2) Whole meal or Graham breads included codes " $M C$ " and "GC" (cores). (3) Brown wheat breads included "BC1" (non-packed, from the market) and "BC2" (from the manufacturer). For comparison of KFT kinetic data, the shell (up to $1.5 \mathrm{~mm}$ from the outer surface of the bread) and pre-dried bread samples were included in the study. The shell samples were coded as "MS" or "BS" (whole meal and brown wheat bread shell samples, respectively), while the pre-dried samples were coded as " $C d$ " and "Sd" for core and shell, respectively. Pre-drying was performed at $37^{\circ} \mathrm{C}$ in the oven with forced convection for $30 \mathrm{~min}$, in order to evaporate the "surface" water and to compare the KFT kinetic parameters. All bread samples were kept in the dark at room temperature, in sealed bags prior analysis. Representative core and shell samples were prepared right before analysis by cutting in cubic portions with a side of $1-1.5 \mathrm{~mm}$. Weighted samples were immediately sealed in the KF sample transfer unit until analysis.

\subsection{Volumetric Karl Fischer Water Titration (KFT)}

The water content of bread samples as well as the KFT kinetics were obtained using the volumetric bi-component KFT method. A Karl Fischer 701 Titrando apparatus equipped with a 10-mL dosing system and a 703 Ti Stand mixing system were used (Metrohm AG, Herisau, Switzerland). Component 1 was Titrant 5 apura ${ }^{\circledR}$ and Component 2 Solvent apura ${ }^{\circledR}$ (Merck\&Co., Inc., Darmstadt, Germany). The titer of $4.4286 \mathrm{mg} / \mathrm{mL}$ for Component 1 was obtained using Water standard $1 \%$ apura ${ }^{\circledR}$, standard for volumetric Karl Fisher titration (Merck\&Co., Inc.). The sample amount was in the range of $0.057-0.419 \mathrm{~g}$ (Table 1). The following KFT parameters were used: $I$ (pol) $50 \mu \mathrm{A}$, end point $250 \mathrm{mV}$, maximum rate $5 \mathrm{~mL} / \mathrm{min}$, stop criterion of drift, stop drift $15 \mu \mathrm{L} / \mathrm{min}$ and temperature of $25 \pm 1{ }^{\circ} \mathrm{C}$. Measurements were done in triplicate (unless otherwise stated).

The KFT kinetics was performed for pseudolinear ranges from the titration curves. The mean water reaction rate depends on the diffusion of water molecules to the sample surface during extraction and analysis. The water reaction rate can be determined by knowing the variation of the titration volume of Component 1 (iodine solution with known titer) on time, as well as the reaction volume 
(the volume of the working medium was $60 \mathrm{~mL}$ in all cases) (Figure 1). This variation of the iodine concentration on time for three pseudolinear ranges was obtained from the Volume (normalized to the sample mass) versus Time curve. This was the mean iodine or water reaction rate on the specified time range (expressed as $\mathrm{mmol} / \mathrm{L} / \mathrm{s}$ or $\mathrm{mM} / \mathrm{s}$ ).

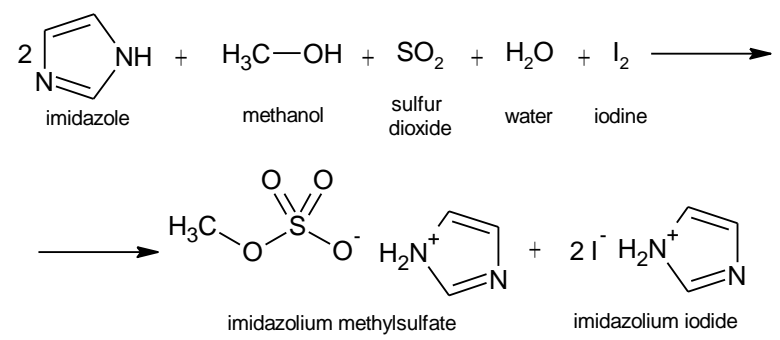

Figure 1. The overall KFT redox reaction (in the first step, methanol, sulfur dioxide and imidazole from Component 2 react and provide imidazolium methyl sulfite; in the second step, the latter reacts with the water from the sample and iodine from Component 1 , providing imidazolium methyl sulfate and imidazolium iodide).

\subsection{Statistics and Principal Component Analysis (PCA)}

The KFT water content and values for KFT kinetic parameters were provided as mean ( \pm standard deviation, SD). Moreover, the results from KFT analysis and kinetics for bread core, pre-dried bread core, raw and pre-dried bread shell samples were compared for significant difference using Tukey's HSD (honestly significant difference) test from the one-way ANOVA module in Statistica 7.1 software (StatSoft, Inc., Tulsa, OK, USA). KFT volume/sample mass ratio $(V / m(\mathrm{~mL} / \mathrm{g}))$, water content $(W)(\%)$, variation of the KFT volume/sample mass on time $(\Delta(V / m) / \Delta t)(\mathrm{mL} / \mathrm{g} / \mathrm{s})$ and the mean KFT reaction rate $(v)(\mathrm{mM} / \mathrm{s})$ were used as dependent variables. The categorical predictor (factor) was the bread sample code (HC (white wheat bread core), MC (whole meal bread core), GC (Graham bread core_, BC (brown wheat bread core), MS (whole meal bread shell, BS (brown wheat bread shell), MCd (pre-dried whole meal bread core), $B C d$ (pre-dried brown wheat bread core), $M S d$ (pre-dried whole meal bread shell) and $B C d$ (pre-dried brown wheat bread shell)). The parameterization was sigma-restricted, while the confidence limit and significance level were set at 0.95 and 0.05 , respectively. PCA is a multivariate statistical tool providing information on similarity/dissimilarity between bread samples, as well as the influence of independent variables for grouping. Both titration and kinetic parameters from the KFT analysis were used for PCA. This technique approximates the data matrix as a product of two reduced matrices that retain only the useful information. $P C_{1}$ (Factor 1, Principal Component 1 ) is that direction from the property space characterized by a maximum variance of the data. $P C_{2}$ (Factor 2, Principal Component 2) also has a maximum variance of the data but restricted by orthogonality to the first component. Other PCs can be obtained in the same manner, but only few $P C s$ will retain the main information from all KFT data. The scores matrix vectors will provide information about similarity/dissimilarity of the samples (grouping of the cases). The loadings matrix vectors will provide the similarity/dissimilarity of properties, as well as the influence of the properties to the model. PC\&CA module from Statistica 7.1 package (StatSoft), with centered data and cross-validation method, were used for PCA analysis of the KFT data.

\section{Results}

\subsection{Karl Fischer Water Titration and Kinetics for Bread Samples}

The water content of bread core samples varies in the range of $39-44.2 \%$ (Table 1 ). The highest water content of white wheat bread samples was obtained for commercial non-packed samples $(43.1 \%)$, but with a higher standard deviation (probably due to a reduced uniformity of samples). This aspect was observed also for white bread roll samples, which were non-packed commercial products (39-39.4\% 
water content, with relatively high SD). The lowest SD in the case of white bread was obtained for the homemade samples; the KFT water content in this case was $41 \%$ (Table 1). The Graham samples have the lowest water content $(36.5 \%)$, while the whole meal and brown bread water content depends on the sample source: the commercial whole meal and brown bread samples have higher water content $(\sim 44 \%)$, in comparison with the samples obtained directly from the manufacturer $(35.1 \%)$; this difference can be explained by the possible use of other recipes and/or processing technique for the product from the market (i.e., colorant additives are indicated on the label).

Completely different results were obtained after pre-drying of the white bread core samples (Table 1). The water content after pre-drying is approximately the same for whole meal bread and brown bread core samples $(\sim 31 \%)$, in comparison with the total water content of $44 \%$ without pre-drying.

A similar approach was applied for some shell samples, without or with pre-drying. KFT water content of these samples was obtained only for comparison of the KFT kinetics and evaluating the corresponding parameters for similarity/dissimilarity of samples by PCA. The water content of the bread shell samples decreased to half in comparison with the core samples $(22.9 \%$ and $19.4 \%$ for whole meal and brown bread shell samples, respectively, in comparison with $\sim 44 \%$ for the corresponding core samples). On the other hand, the pre-drying of shell samples consistently decreased the water content (from $22.9 \%$ to $1.1 \%$ for whole meal bread shell and from $19.4 \%$ to $4.7 \%$ for brown bread shell samples, Table 1).

Table 1. KFT results for bread core samples, pre-dried bread core samples, as well as raw and pre-dried bread shell samples. Values are expressed as mean ( \pm standard deviation, SD) of triplicate analysis (excepting * for duplicate or single analysis).

\begin{tabular}{|c|c|c|c|c|c|}
\hline No. & Code & $\begin{array}{l}\text { Sample Mass } \\
\text { (g) }\end{array}$ & $\begin{array}{l}\text { KFT Volume } \\
(\mathrm{mL})\end{array}$ & $\begin{array}{l}\text { KFT Volume/Sample Mass Ratio } \\
\qquad(\mathrm{mL} / \mathrm{g})^{1}\end{array}$ & $\begin{array}{l}\text { Water Content } \\
(\%)^{1}\end{array}$ \\
\hline 1 & $H C 1$ * & $0.0768( \pm 0.0149)$ & $3.223( \pm 0.498)$ & $42.16( \pm 1.71)^{\mathrm{a}}$ & $43.12( \pm 6.66)^{a}$ \\
\hline 2 & HC2 & $0.0572( \pm 0.0070)$ & $2.554( \pm 0.291)$ & $44.66( \pm 0.84)^{\mathrm{a}}$ & $39.56( \pm 0.74)^{\mathrm{a}}$ \\
\hline 3 & HC3 & $0.0656( \pm 0.0178)$ & $2.902( \pm 0.860)$ & $43.16( \pm 0.18)^{\mathrm{a}}$ & $39.04( \pm 1.00)^{\mathrm{a}}$ \\
\hline 4 & HC4 & $0.4192( \pm 0.5131)$ & $3.002( \pm 0.799)$ & $44.05( \pm 1.85)^{\mathrm{a}}$ & $39.37( \pm 1.47)^{\mathrm{a}}$ \\
\hline 5 & $H C 5$ * & $0.0690( \pm 0.0141)$ & $2.894( \pm 0.566)$ & $41.69( \pm 0.71)^{\mathrm{a}}$ & $41.06( \pm 0.34)^{\mathrm{a}}$ \\
\hline 6 & GC & $0.1288( \pm 0.0600)$ & $5.328( \pm 2.491)$ & $40.57( \pm 1.49)^{\mathrm{a}}$ & $36.50( \pm 1.32)^{b}$ \\
\hline 7 & $M C$ & $0.0850( \pm 0.0032)$ & $3.884( \pm 0.187)$ & $46.45( \pm 0.97)^{a}$ & $44.23( \pm 1.14)^{\mathrm{a}}$ \\
\hline 8 & $B C 1$ & $0.0837( \pm 0.0018)$ & $3.777( \pm 0.135)$ & $44.06( \pm 0.59)^{\mathrm{a}}$ & $44.11( \pm 0.61)^{\mathrm{a}}$ \\
\hline 9 & $B C 2$ & $0.0631( \pm 0.0376)$ & $2.297( \pm 1.370)$ & $37.86( \pm 1.70)^{a b}$ & $35.15( \pm 0.35)^{b}$ \\
\hline 10 & $M C d *$ & 0.0851 & 2.731 & $32.43^{\mathrm{b}}$ & $31.06^{\mathrm{c}}$ \\
\hline 11 & $B C d$ & 0.0851 & 2.752 & $32.74^{\mathrm{b}}$ & $31.30^{\mathrm{c}}$ \\
\hline 12 & MS & $0.0909( \pm 0.0014)$ & $2.154( \pm 0.081)$ & $22.95( \pm 1.01)^{\mathrm{c}}$ & $22.94( \pm 1.05)^{\mathrm{d}}$ \\
\hline 13 & $M S d *$ & 0.0915 & 0.099 & $23.61^{\mathrm{c}}$ & $1.05^{\mathrm{e}}$ \\
\hline 14 & BS & $0.0811( \pm 0.0084)$ & $1.656( \pm 0.572)$ & $17.56( \pm 4.04)^{\mathrm{d}}$ & $19.44( \pm 4.72)^{\mathrm{d}}$ \\
\hline 15 & $B S d^{*}$ & 0.0926 & 0.452 & $5.35^{\mathrm{e}}$ & $4.72 \mathrm{e}$ \\
\hline
\end{tabular}

The aspect of Volume/sample mass $(\mathrm{V} / \mathrm{m})$ versus Time titration curves from the KFT analysis are very different for bread samples (Figures 2 and 3; see also Figures S1 and S2). Only two pseudolinear ranges were observed for all white bread samples and Graham bread samples, while whole meal and brown bread samples provide three pseudolinear ranges. The water reaction rates for white bread core samples, corresponding to "surface" water molecules, are in the range of 2.4-3.2 mM/s, the highest being determined for packed samples (code "HC2", Table 2). The Graham bread samples have similar behavior, but the water reaction rate for the first interval is lower $(1.67 \mathrm{mM} / \mathrm{s})$, while that for the second interval is in the same range $(0.06 \mathrm{mM} / \mathrm{s})$. Different results were obtained in the case of brown bread samples: the samples obtained from the market (containing colorants as additives) have similar behavior such as white bread samples (code "BC1", $2.17 \mathrm{mM} / \mathrm{s}$ for $v_{1}$ and $0.097 \mathrm{mM} / \mathrm{s}$ for $v_{2}$ ). It can be due to different recipes used, in comparison with the similar sample obtained from the 
manufacturer. Higher water reaction rates for both first and second interval (3.9-4.2 and $0.2-0.5 \mathrm{mM} / \mathrm{s}$, respectively) were obtained in the case of whole meal bread and brown bread samples obtained from the manufacturer (code " $B C 2$ "). Even the core samples were pre-dried in the oven (the "surface" water was partially removed), these water reaction rates remain approximately the same (3.8-4 mM/s for the first interval and $0.3-0.5 \mathrm{mM} / \mathrm{s}$ for the second one). Some KFT analyses were performed on bread shell samples, but the results have high SDs in most cases (probably due to the higher hygroscopicity of the crust). The water reaction rates corresponding to the "surface" water molecules are relatively low $(0.8-2.1 \mathrm{mM} / \mathrm{s})$, while those corresponding to "strongly retained" water molecules vary in a wide range $\left(0.32-0.44\right.$ and $0.06-0.3 \mathrm{mM} / \mathrm{s}$ for whole meal and brown bread samples, respectively, Table 2; $v_{3}$ values are presented in Table S1).

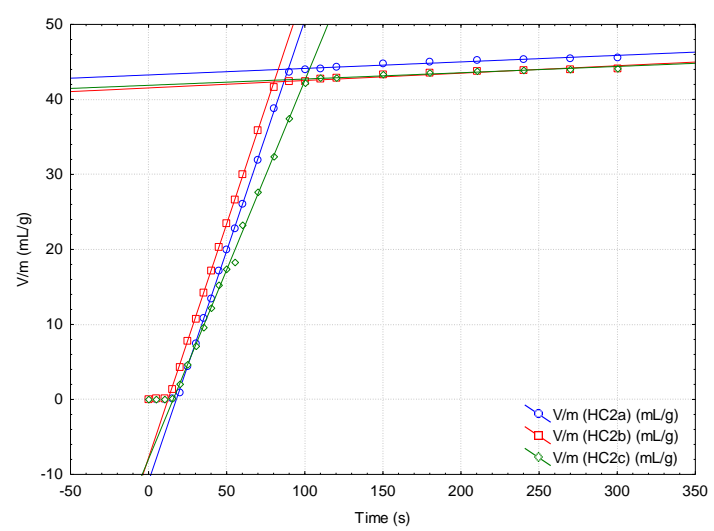

(a)

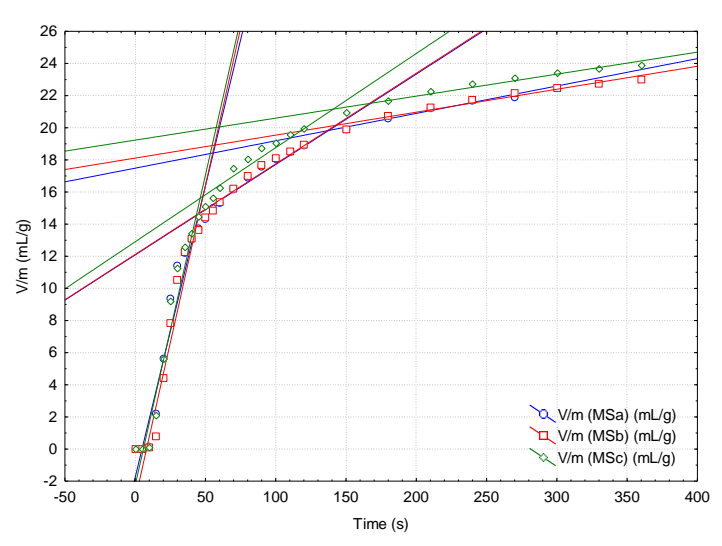

(b)

Figure 2. The Volume/sample mass $(\mathrm{V} / \mathrm{m})$ versus Time titration curves from KFT analysis of the selected bread samples (triplicates): (a) white wheat bread, sliced and packed in plastic bag (core), code "HC2"; and (b) whole meal wheat bread (shell), code " $M S^{\prime}$.

Table 2. The mean KFT water reaction rates (based on the variation of the normalized KFT volume on time, $\Delta(V / m) / \Delta t)$ on the first two time ranges (pseudolinear) for bread core samples, pre-dried bread core samples and raw and pre-dried bread shell samples Values are expressed as mean ( \pm standard deviation, SD) of triplicate analysis (except * for duplicate or single analysis).

\begin{tabular}{|c|c|c|c|c|c|}
\hline No. & Code & $\begin{array}{c}\text { Variation of the KFT } \\
\text { Volume/Sample Mass on Time } \\
{\left[\Delta(V / m)_{1} / \Delta t_{1}, \mathrm{~mL} / \mathrm{g} / \mathrm{s}\right]^{1}}\end{array}$ & $\begin{array}{c}\text { Variation of the KFT } \\
\text { Volume/Sample Mass on Time } \\
\left.[\Delta V / m)_{2} / \Delta t_{2}, \mathrm{~mL} / \mathrm{g} / \mathrm{s}\right]^{1}\end{array}$ & $\begin{array}{c}\text { Mean KFT } \\
\text { Reaction Rate } \\
v_{2}(\mathrm{mM} / \mathrm{s})^{1}\end{array}$ & $\begin{array}{c}\text { Mean KFT } \\
\text { Reaction Rate } \\
v_{2}(\mathrm{mM} / \mathrm{s})^{1}\end{array}$ \\
\hline 1 & $H C 1$ * & $0.434( \pm 0.078)^{\mathrm{a}}$ & $0.0039( \pm 0.0027)^{\mathrm{a}}$ & $2.42( \pm 0.43)^{a}$ & $0.022( \pm 0.015)^{\mathrm{a}}$ \\
\hline 2 & HC2 & $0.581( \pm 0.066)^{\mathrm{a}}$ & $0.0090( \pm 0.0008)^{\mathrm{a}}$ & $3.23( \pm 0.37)^{a}$ & $0.050( \pm 0.004)^{\mathrm{a}}$ \\
\hline 3 & HC3 & $0.503( \pm 0.124)^{\mathrm{a}}$ & $0.0192( \pm 0.0093)^{\mathrm{a}}$ & $2.80( \pm 0.69)^{a}$ & $0.107( \pm 0.052)^{\mathrm{a}}$ \\
\hline 4 & HC4 & $0.495( \pm 0.112)^{\mathrm{a}}$ & $0.0127( \pm 0.0067)^{\mathrm{a}}$ & $2.75( \pm 0.62)^{a}$ & $0.071( \pm 0.037)^{\mathrm{a}}$ \\
\hline 5 & $\mathrm{HC} 5$ * & $0.483( \pm 0.107)^{a}$ & $0.0139( \pm 0.0015)^{\mathrm{a}}$ & $2.68( \pm 0.59)^{a}$ & $0.077( \pm 0.008)^{\mathrm{a}}$ \\
\hline 6 & GC & $0.301( \pm 0.156)^{a b}$ & $0.0111( \pm 0.0093)^{\mathrm{a}}$ & $1.67( \pm 0.87)^{a b}$ & $0.062( \pm 0.052)^{\mathrm{a}}$ \\
\hline 7 & $M C$ & $0.762( \pm 0.024)^{\mathrm{c}}$ & $0.0380( \pm 0.0056)^{b}$ & $4.24( \pm 0.13)^{c}$ & $0.211( \pm 0.031)^{b}$ \\
\hline 8 & $B C 1$ & $0.389( \pm 0.004)^{\mathrm{a}}$ & $0.0175( \pm 0.0034)^{\mathrm{a}}$ & $2.17( \pm 0.02)^{a}$ & $0.097( \pm 0.019)^{\mathrm{a}}$ \\
\hline 9 & $B C 2$ & $0.708( \pm 0.083)^{c}$ & $0.0848( \pm 0.0086)^{c}$ & $3.94( \pm 0.46)^{c}$ & $0.472( \pm 0.048)^{\mathrm{c}}$ \\
\hline 10 & $M C d^{*}$ & $0.717^{\mathrm{c}}$ & $0.0557^{\mathrm{d}}$ & $3.99^{c}$ & $0.310^{\mathrm{d}}$ \\
\hline 11 & $B C d^{*}$ & $0.682^{\mathrm{c}}$ & $0.0857^{\mathrm{cd}}$ & $3.79^{c}$ & $0.476^{\mathrm{cd}}$ \\
\hline 12 & MS & $0.380( \pm 0.015)^{\mathrm{a}}$ & $0.0571( \pm 0.0013)^{d}$ & $2.12( \pm 0.09)^{a}$ & $0.318( \pm 0.007)^{d}$ \\
\hline 13 & $M S d^{*}$ & $0.136^{\mathrm{d}}$ & $0.0785^{c}$ & $0.76^{\mathrm{d}}$ & $0.436^{c}$ \\
\hline 14 & $B S *$ & $0.180^{\mathrm{d}}$ & $0.0533^{\mathrm{d}}$ & $1.00^{\mathrm{d}}$ & $0.296^{d}$ \\
\hline 15 & $B S d^{*}$ & $0.205^{d}$ & $0.0108^{a}$ & $1.14^{\mathrm{d}}$ & $0.060^{\mathrm{a}}$ \\
\hline
\end{tabular}

${ }^{1}$ For a given parameter (variation of the KFT volume/sample mass on time $(\Delta(V / m) / \Delta t)$ and mean KFT reaction rate $(v))$, values with different letters are significantly different, according to Tukey's HSD (honestly significant difference) test $(p<0.05)$. All $p$-level values are presented in the Supplementary Materials (Tables S4 and S5). 


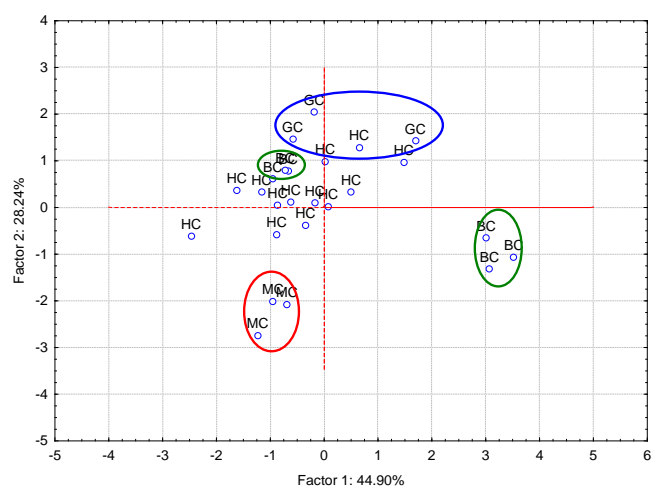

(a)

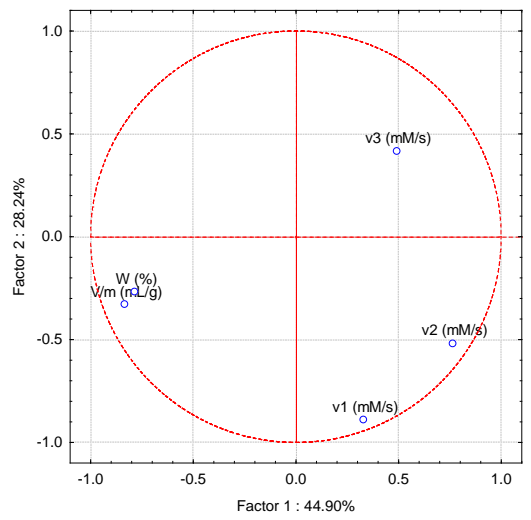

(c)

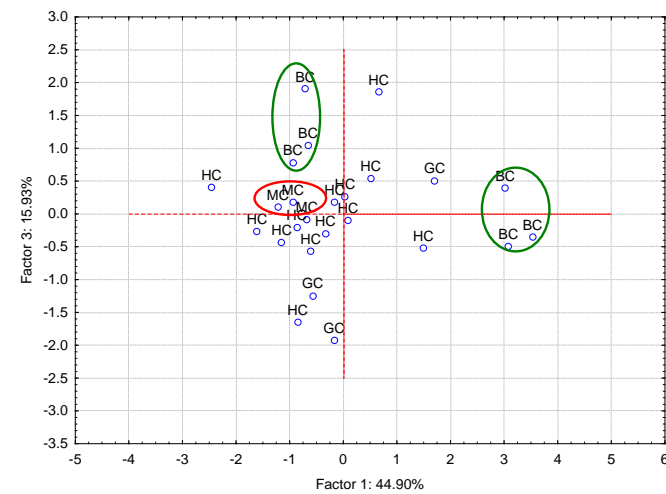

(b)

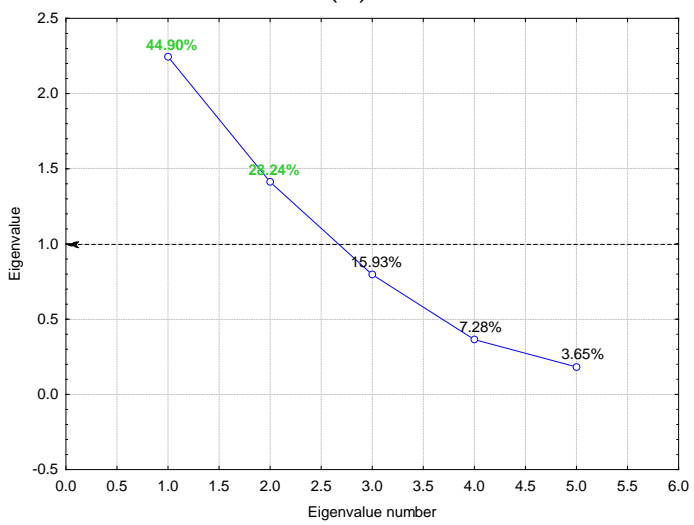

(d)

Figure 3. PCA results for the KFT data of bread core samples: (a) $P C_{2}$ versus $P C_{1}$ scores plot; (b) $P C_{3}$ versus $P C_{1}$ scores plot; (c) $P C_{2}$ versus $P C_{1}$ loadings plot; and (d) eigenvalues of the correlation matrix. Meaning of color lines in (a,b): Green-brown wheat bread core (code " $B C^{\prime \prime}$ ); red-whole meal bread core (code " $M C^{\prime \prime}$ ); blue-Graham bread core (code "GC"). Meaning of color lines in (d): Green numbers - relevant eigenvalues.

\subsection{Principal Component Analysis on KFT Data for Bread Samples}

Valuable classifications were obtained in the case of bread samples using PCA technique. All white bread core samples were located in the center of the scores plot, but less grouped (codes " $H C^{\prime}$ ", Figure $3 \mathrm{a}, \mathrm{b}$ ). The whole meal and brown bread core samples are well grouped, according to both $P C_{2}$ versus $P C_{1}$ and $P C_{3}$ versus $P C_{1}$ scores plots (codes " $B C^{\prime}$ " (two groups) and " $M C^{\prime \prime) . ~ S o m e ~ b r o w n ~ b r e a d ~}$ samples are more similar with white bread samples (samples from the market). Graham bread samples are partially similar with white bread; they are grouped in the upper side of the $P C_{2}$ versus $P C_{1}$ scores plot (code "GC").

Evident grouping was observed from PCA analysis of the KFT water reaction rate data for core, " $C$ " and shell " $S$ " bread samples. The core samples are especially located in the center of the scores plot, while shell samples were classified in the left of this plots (both $P C_{2}$ versus $P C_{1}$ and $P C_{3}$ versus $P C_{1}$, Figure $\left.4 a, b\right)$. These classifications are due to the KFT water content and normalized volume $(W$ and $V / m)$, as well as KFT reaction rates corresponding to "strongly retained" water for $P C_{1}\left(v_{2}\right.$ and $\left.v_{3}\right)$ and to KFT reaction rates corresponding to both "surface" and "strongly retained" water for $P C_{2}$ $\left(v_{1}\right.$ and $v_{2}$, Figures $3 \mathrm{c}$ and $\left.4 \mathrm{c}\right)$. The water reaction rate corresponding to the "normal" drift in the KFT process has weak influence in the multivariate analysis. The first two PCs are enough to retain the important information from the KFT data, according to eigenvalues of the correlation matrix from the PCA analysis (Figures $3 \mathrm{~d}$ and $4 \mathrm{~d}$ ). These PCS explain $73.14 \%$ and $80.43 \%$ from the variance of the KFT data corresponding to bread core samples and all bread core and shell samples, respectively. Other PCA results are presented in the Supplementary Materials (Figures S3 and S4). 


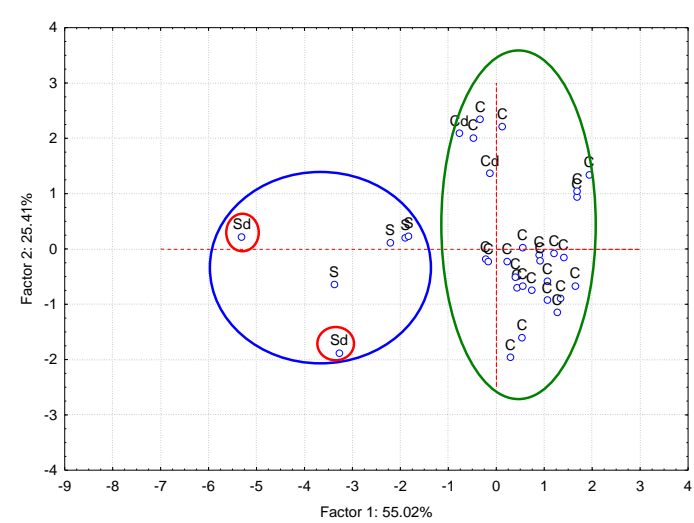

(a)

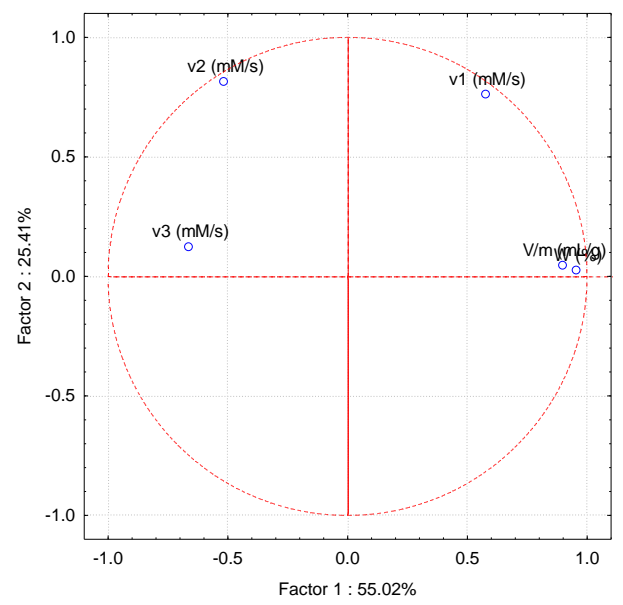

(c)

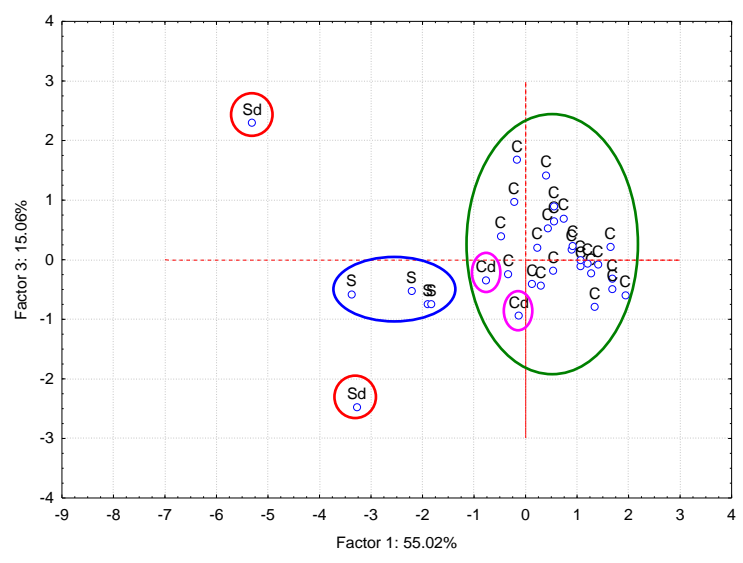

(b)

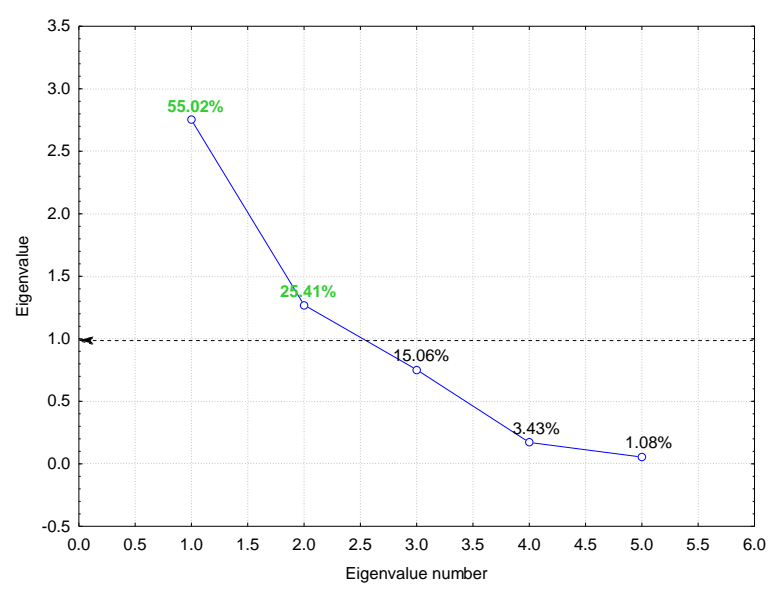

(d)

Figure 4. PCA results for the KFT data of all bread core and shell samples: (a) $P C_{2}$ versus $P C_{1}$ scores plot; (b) $P C_{3}$ versus $P C_{1}$ scores plot; (c) $P C_{2}$ versus $P C_{1}$ loadings plot; and (d) eigenvalues of the correlation matrix. Meaning of color lines in $(\mathbf{a}, \mathbf{b})$ : Green-raw bread core (code " $C$ "); pink-pre-dried bread core (code " $C d^{\prime}$ ); blue—raw bread shell (code " $S$ "); red-pre-dried bread shell (code "Sd"). Meaning of color lines in (d): Green numbers-relevant eigenvalues.

\section{Discussion}

Water determination in bread samples is a challenge. The real water content of such complex food matrices is difficult to evaluate. There are many factors influencing the results, starting from the selection of the method to the composition and sample preparation. The water content ranges in the common values $[20,26,48,49]$, but with differences between bread samples. However, the water content of bread was close to the upper limit of the common range of water content values determined with standard thermal methods or even higher, if the two-component volumetric KFT technique was applied $[48,49]$. The explanation is that the KFT is sensitive to water, while other methods such as oven drying determines the mass loss. This includes all volatiles that evaporate at the selected temperature, especially water but also aroma compounds. On the other hand, drying at elevated temperature can induces changes in the sample, sometimes with generation of volatiles [27,31-33,50]. KFT analysis allows selecting the polarity of the solvent according to sample type and a temperature program for a complete extraction and titration of water [3,37-39]. Generally, water content of non-packed bread or fresh from the manufacturer is higher, most probably due the water absorption from the environment during storage, transportation and commercialization. Ayub et al. (2003) evaluated the moisture content by oven drying and water activity of bread samples during storage. The moisture 
content increased by a few percent (sometimes by $12 \%$ ) after four days, while the water activity also increased [20]. The water content of the bread crumb during the baking process can increase up to $2.5 \%$, followed by a slow decrease up to the final baking step [51]. The maximum moisture content of the core can reach $51 \%$, depending on the composition and baking conditions [26].

The differences between KFT water content of core (crumb) and shell (crust) of breads are obvious, the crust having consistently lower values (about half in comparison with the corresponding cores, Table 1). On the other hand, pre-drying of core and shell samples reveals completely different comparative values. Pre-drying lowered the water content of core samples only by a third, while the shell samples by $75-95 \%$. It is clear that most of the water in the core samples are strongly retained, in comparison with that from shell samples, where a significant water fraction is "surface" water. This behavior can be explained by the presence in the bread core of less degraded starch and gluten, as well as other proteins, which absorb higher quantity of water. The absorbed water molecules are strongly retained by such flour and bread components. On the other hand, the bread crust (shell) has higher fraction of consistently degraded components and the absorbed water is mainly "surface" water. These water molecules are easily evaporated [3,52-54]. Ureta and co-workers (2018) performed baking tests and oven drying moisture determinations on various regions on the bread. The top crust had a moisture content at the final of the baking process of 3.7-9.5\%, depending on the baking temperature. The upper, lower and core crumb regions had approximately constant moisture content during baking, with a slight increase at the end of the baking process (up to $42-43 \%$ ). On the contrary, the moisture content of various crust regions consistently decreases during baking process [26,51].

There is a correlation between the water content determined by oven drying technique and water activity of food products. This is due to the fact that both are related through the sorption isotherm and the water content can be indirectly determined if the sorption isotherm and water activity are known [31]. Such correlation can be observed for the bran-based bread crumb. An increasing of the oven drying water content of bread crumb after the addition of bran fractions from $41 \%$ to $43 \%$ is correlated with an increasing of the water activity from 0.96 to 0.97 [13,55]. This is particularly due to the influence of bran on the starch-gluten-water interactions. Similar observations have been made for bread obtained with potato fiber in order to improve the product characteristics during storage [56]. On the other hand, the crust and under-crust of various traditional sourdough bread types had a water content of $19 \%$ and $23 \%$, respectively (determined by oven drying). The corresponding crumb samples had a water content of $\sim 46.4 \%$. They are well correlated with the water activity. The crust had a water activity of $0.76-0.77$, while this parameter was consistently higher for the crumb ( 0.97). However, no significant changes on the water activity during eight days of storage have been observed [57]. Such correlations, including the influence on the crispness, fragility and plasticity, have also been obtained for flat extruded wheat and rye breads or bread spread samples containing eggshell powders $[58,59]$. Regarding the bread crust and crumb, there are many studies related to the influence of various ingredients on the water activity, water content and other physical chemical characteristics [60-65]. No studies on the correlation of the water content determined by KFT and water activity of bread have been made. However, such correlation cannot be simply made due to very different conditions of measurements. Water activity is the ratio between the partial vapor pressure of water in the food sample and the standard state partial vapor pressure of water, which is supposed to be analyzed in gaseous state. On the contrary, the KFT water content is determined in solution or suspension (the case of bread samples), which means water extraction in the liquid working medium.

To our knowledge, no significant studies on the application of KFT for evaluating the types of water molecules in bread have been performed. The strength of physically bonding of water molecules into a less soluble samples can be evaluated from the KFT curve. An efficient and simple way is based on KFT kinetics, especially the mean water reaction rates on specific time ranges. Only few studies on the KFT kinetics for estimating the water content in solids (i.e., magnesium gluconate dihydrate or sucrose) or solutions have been published [66,67]. Our previous studies demonstrate the possibility to evaluate the "surface" and "strongly retained" water molecules in solid samples by KFT 
kinetics [3,35-37,68-70]. The "surface" water molecules are weak bonded on the surface of the solid particle, especially by hydrogen bonding. They appear by absorption during storage, transportation and even prior analysis of a less soluble solid or semi-solid sample. They also exist in the raw samples. "Surface" water molecules are easily disposable to the KFT working medium and react quickly. This is observed on the first pseudolinear range of the KFT curve and are similar to the KFT water reaction in completely soluble samples $[31,33]$. On the other hand, "strongly retained" water molecules (physically bonded in the interior of the less soluble solid or semi-solid particles) react at a much slower rate, which principally depends on the diffusion of these water molecules to the surface of sample particles. Thus, this KFT water reaction rate consistently depends on the particle surface or dimensions. It is the case of bread samples, which are heterogeneous particles. The reaction rate of the "strongly retained" water molecules in the bread core samples is very different for white bread and whole meal or brown bread samples due to the heterogeneity and level of degradation in the last case. Moreover, this "strongly retained" water reaction rate can be easily determined for bread shell samples (Figure 2). Generally, water reaction rates are more than twenty times higher for "surface" water molecules in bread core samples, in comparison with the case of bread shell samples $\left(v_{1}\right.$ is up to seven times higher than $v_{2}$, Table 2).

The absolute values for the KFT kinetic parameters are difficult to evaluate in order to identify the similarity/dissimilarity of the samples and the corresponding influence of these parameters. The multivariate analysis techniques are the most appropriate for such evaluation. One of these techniques is PCA, which is often used in food analysis. The bread samples are well classified if KFT parameters have been applied to PCA, especially for whole meal and brown bread samples. Moreover, core and shell samples are obviously grouped by means of KFT kinetic parameters. The KFT water reaction rates corresponding to "surface" and "strongly retained" water molecules (i.e., $v_{1}$ and $v_{2}$, respectively) are more important for discriminating along the second $P C$, while the parameters related to the final KFT water content are important for the first $P C$ (Figures $3 c$ and $4 \mathrm{c}$ ). The latter clearly influence the discrimination between core and shell samples (the " $C$ " (core) and " $S$ " (shell) groups are separated along $P C_{1}$, Figure $4 a$ ), while the bread types are discriminated by KFT kinetic parameters, along $P C_{2}$ (Figure 3a). These two $P C$ s retain the most useful information related for such discriminations and classifications (Figures $3 \mathrm{~d}$ and $4 \mathrm{~d}$ ). The behavior of bread samples are similar to other less soluble samples such as cereal flour [3,36], meat products [35], cyclodextrins and their complexes [37,68-70].

\section{Conclusions}

This is the first study on the coupling of Karl Fischer water titration technique with a multivariate statistical analysis method in order to differentiate bread samples through water reaction kinetics. The first two principal components in PCA analysis explain more than $70 \%$ of the variance of the KFT data. The bread core and shell samples are completely dissimilar if the "surface" and "strongly retained" KFT water reaction rates are considered. Moreover, whole meal and white wheat bread samples are clearly differentiated through the same water reaction rates. These are correlated with the composition and the way of bonding of water molecules in the bread particles used in the KFT measurement, but the KFT-PCA technique does not need compositional information for discrimination. KFT is selective for water, while other methods such as oven drying determine the overall mass change ("moisture content", which are also comprises of other volatile compounds).

Consequently, the overall KFT titration parameters could be used for discriminating by sample region or parts, while KFT kinetics for classifications by sample types. However, such KFT-PCA coupling technique needs appropriate calibrations and model systems, possibly a database for every type of samples (e.g., bread products and specific solid ingredients for food such as flour, dairy products, etc.). 
Supplementary Materials: The following are available online at http://www.mdpi.com/2076-3417/10/18/6518/s1, Figure S1: The Volume/sample mass $(\mathrm{V} / \mathrm{m})$ versus Time titration curves from KFT analysis of the bread samples, Figure S2: The Volume/sample mass $(V / m)$ versus Time titration curves from KFT analysis of the pre-dried core, shell and pre-dried shell of bread samples, Table S1: The mean KFT water reaction rates on the third time range (pseudolinear, the "normal" drift) for the core, pre-dried core, shell and pre-dried shell of bread samples, Table S2: Significance levels ( $p$-level) from the Tukey's HSD (honestly significant difference) test for the KFT volume/sample mass ratio $(V / m)(\mathrm{mL} / \mathrm{g})$ in the case of KFT analysis of all bread samples, Table S3: Significance levels $(p$-level) from the Tukey's HSD (honestly significant difference) test for the water content $(W)(\%)$ in the case of KFT analysis of all bread samples, Table S4: Significance levels ( $p$-level) from the Tukey's HSD (honestly significant difference) test for the mean KFT reaction rate for the first time range $\left(v_{1}\right)(\mathrm{mM} / \mathrm{s})$ in the case of KFT analysis of all bread samples, Table S4: Significance levels ( $p$-level) from the Tukey's HSD (honestly significant difference) test for the mean KFT reaction rate for the second time range $\left(v_{2}\right)(\mathrm{mM} / \mathrm{s})$ in the case of KFT analysis of all bread samples, Figure S3: PCA results for the KFT data of bread core samples, Figure S4: PCA results for the KFT data of all bread core and shell samples.

Author Contributions: Conceptualization, D.I.H. and N.G.H.; methodology, G.P., I.R., O.A.I., D.I.H., N.G.H. and M.R.; validation, D.I.H. and N.G.H.; formal analysis, D.I.H. and N.G.H.; investigation, L.R., D.I.H., C.A.L. and N.G.H.; resources, M.D.O., M.D., G.S.B. and I.D.; writing-original draft preparation, D.I.H. and N.G.H.; writing-review and editing, G.P., I.R., O.A.I., D.I.H., N.G.H. and M.R.; supervision, N.G.H.; project administration, N.G.H.; and funding acquisition, I.R. and N.G.H. All authors have read and agreed to the published version of the manuscript.

Funding: This research was funded by Ministry of Research and Innovation of Romania, Executive Unit for Financing Higher Education, Research, Development and Innovation (UEFISCDI), grant PNCDI III 2015-2020-ID 368, institutional development project "Ensuring excellence in R\&D within USAMVBT", from the institutional performance subprogram 1.2, development of the R\&D national system program 1.

Acknowledgments: The authors thank Heinz-Dieter Isengard (University of Hohenheim, Germany) for the help with the KFT equipment and analysis, as well as to Simona Funar-Timofei ("Coriolan Drăgulescu" Institute of Chemistry, Romanian Academy) for the help with Statistica 7.1 software.

Conflicts of Interest: The authors declare no conflict of interest. The funders had no role in the design of the study; in the collection, analyses, or interpretation of data; in the writing of the manuscript, or in the decision to publish the results.

\section{References}

1. Dewettinck, K.; Van Bockstaele, F.; Kühne, B.; Van de Walle, D.; Courtens, T.M.; Gellynck, X. Nutritional value of bread: Influence of processing, food interaction and consumer perception. J. Cereal Sci. 2008, 48, 243-257. [CrossRef]

2. Goesaert, H.; Brijs, K.; Veraverbeke, W.S.; Courtin, C.M.; Gebruers, K.; Delcour, J.A. Wheat flour constituents: How they impact bread quality, and how to impact their functionality. Trends Food Sci. Technol. 2005, 16, 12-30. [CrossRef]

3. Hădărugă, D.I.; Costescu, C.I.; Corpaş, L.; Hădărugă, N.G.; Isengard, H.-D. Differentiation of rye and wheat flour as well as mixtures by using the kinetics of Karl Fischer water titration. Food Chem. 2016, 195, 49-55. [CrossRef] [PubMed]

4. Mondal, A.; Datta, A.K. Bread baking-A review. J. Food Eng. 2008, 86, 465-474. [CrossRef]

5. Lopes Almeida, E.; Chang, Y.K.; Joy Steel, C. Dietary fibre sources in bread: Influence on technological quality. LWT Food Sci. Technol. 2013, 50, 545-553. [CrossRef]

6. Xu, J.; Wang, W.; Li, Y. Dough properties, bread quality, and associated interactions with added phenolic compounds: A review. J. Funct. Foods 2019, 52, 629-639. [CrossRef]

7. Birch, A.N.; Petersen, M.A.; Arneborg, N.; Hansen, A.S. Influence of commercial baker's yeasts on bread aroma profiles. Food Res. Int. 2013, 52, 160-166. [CrossRef]

8. Blandino, M.; Sovrani, V.; Marinaccio, F.; Reyneri, A.; Rolle, L.; Giacosa, S.; Locatelli, M.; Bordiga, M.; Travaglia, F.; Coïsson, J.D.; et al. Nutritional and technological quality of bread enriched with an intermediated pearled wheat fraction. Food Chem. 2013, 141, 2549-2557. [CrossRef]

9. Bosmans, G.M.; Lagrain, B.; Fierens, E.; Delcour, J.A. The impact of baking time and bread storage temperature on bread crumb properties. Food Chem. 2013, 141, 3301-3308. [CrossRef]

10. Caballero, P.A.; Gomez, M.; Rosell, C.M. Improvement of dough rheology, bread quality and bread shelf-life by enzymes combination. J. Food Eng. 2007, 81, 42-53. [CrossRef] 
11. Cho, I.H.; Peterson, D.G. Chemistry of Bread Aroma: A Review. Food Sci. Biotechnol. 2010, 19, 575-582. [CrossRef]

12. Corpaş, L.; Hădărugă, N.G.; Codina, G.G.; Riviş, A.; Guran, E.; Baliţa, E.-N.; Hădărugă, D.I. Phospholipids in homemade bread. J. Agroaliment. Process. Technol. 2012, 18, 336-340.

13. Curti, E.; Carini, E.; Bonacini, G.; Tribuzio, G.; Vittadini, E. Effect of the addition of bran fractions on bread properties. J. Cereal Sci. 2013, 57, 325-332. [CrossRef]

14. de Lamo, B.; Gómez, M. Bread enrichment with oilseeds. A Review. Foods 2018, 7, 191. [CrossRef]

15. Goesaert, H.; Slade, L.; Levine, H.; Delcour, J.A. Amylases and bread firming-An integrated view. J. Cereal Sci. 2009, 50, 345-352. [CrossRef]

16. Jiang, D.; Peterson, D.G. Identification of bitter compounds in whole wheat bread. Food Chem. 2013, 141, 1345-1353. [CrossRef]

17. Moayedallaie, S.; Mirzaei, M.; Paterson, J. Bread improvers: Comparison of a range of lipases with a traditional emulsifier. Food Chem. 2010, 122, 495-499. [CrossRef]

18. Shin, D.-J.; Kim, W.; Kim, Y. Physicochemical and sensory properties of soy bread made with germinated, steamed, and roasted soy flour. Food Chem. 2013, 141, 517-523. [CrossRef]

19. Belz, M.C.E.; Ryan, L.A.M.; Arendt, E.K. The Impact of Salt Reduction in Bread: A Review. Crit. Rev. Food Sci. Nutr. 2012, 52, 514-524. [CrossRef]

20. Ayub, M.; Wahab, S.; Durrani, Y. Effect of Water Activity (Aw) Moisture Content and Total Microbial Count on the Overall Quality of Bread. Int. J. Agric. Biol. 2003, 5, 274-278.

21. Chen, G.; Öhgren, C.; Langton, M.; Lustrup, K.F.; Nydén, M.; Swenson, J. Impact of long-term frozen storage on the dynamics of water and ice in wheat bread. J. Cereal Sci. 2013, 57, 120-124. [CrossRef]

22. Miś, A.; Krekora, M.; Niewiadomski, Z.; Dziki, D.; Nawrocka, A. Water redistribution between model bread dough components during mixing. J. Cereal Sci. 2020, 95, 103035. [CrossRef]

23. Gil, M.J.; Callejo, M.J.; Rodriguez, G. Effect of water content and storage time on white pan bread quality: Instrumental evaluation. Z. Lebensm. Unters. Forsch. 1997, 205, 268-273. [CrossRef]

24. Cappelli, A.; Oliva, N.; Cini, E. Stone milling versus roller milling: A systematic review of the effects on wheat flour quality, dough rheology, and bread characteristics. Trends Food Sci. Technol. 2020, 97, 147-155. [CrossRef]

25. Ziobro, R.; Korus, J.; Juszczak, L.; Witczak, T. Influence of inulin on physical characteristics and staling rate of gluten-free bread. J. Food Eng. 2013, 116, 21-27. [CrossRef]

26. Wagner, M.J.; Lucas, T.; Le Ray, D.; Trystram, G. Water transport in bread during baking. J. Food Eng. 2007, 78, 1167-1173. [CrossRef]

27. Margolis, S.A.; Huang, P.H.; Hădărugă, N.G.; Hădărugă, D.I. Water determination. In Encyclopedia of Analytical Science, 3rd ed.; Elsevier: Oxford, UK, 2019; Volume 10, pp. 382-390.

28. Yazgan, S.; Bernreuther, A.; Ulberth, F.; Isengard, H.-D. Water-An important parameter for the preparation and proper use of certified reference materials. Food Chem. 2006, 96, 411-417. [CrossRef]

29. Isengard, H.-D.; Kling, R.; Reh, C.T. Proposal of a new reference method to determine the water content of dried dairy products. Food Chem. 2006, 96, 418-422. [CrossRef]

30. Isengard, H.-D.; Präger, H. Water determination in products with high sugar content by infrared drying. Food Chem. 2003, 82, 161-167. [CrossRef]

31. Isengard, H.-D. Water content, one of the most important properties of food. Food Control. 2001, 12, 395-400. [CrossRef]

32. Heinze, P.; Isengard, H.-D. Determination of the water content in different sugar syrups by halogen drying. Food Control. 2001, 12, 483-486. [CrossRef]

33. Isengard, H.-D. Rapid water determination in foodstuffs. Trends Food Sci. Technol. 1995, 6, 155-162. [CrossRef]

34. Sahin, A.W.; Wiertz, J.; Arendt, E.K. Evaluation of a new method to determine the water addition level in gluten-free bread systems. J. Cereal Sci. 2020, 93, 102971. [CrossRef]

35. Zippenfening, S.E.; Hădărugă, D.I.; Negrea, I.; Velciov, A.; Hădărugă, N.G. Karl Fischer titration of salami products: Variation of the water content during ripening and kinetics of the KFT process. Chem. Bull. Politeh. Univ. Timişoara 2015, 64, 18-24.

36. Corpaş, L.; Hădărugă, N.G.; David, I.; Pîrşan, P.; Hădărugă, D.I.; Isengard, H.-D. Karl Fischer water titration-Principal component analysis approach on wheat flour. Food Anal. Methods 2014, 7, 1353-1358. [CrossRef] 
37. Hădărugă, N.G.; Hădărugă, D.I.; Isengard, H.-D. Water content of natural cyclodextrins and their essential oil complexes: A comparative study between Karl Fischer titration and thermal methods. Food Chem. 2012, 132, 1741-1748. [CrossRef]

38. Felgner, A.; Schlink, R.; Kirschenbuhler, P.; Faas, B.; Isengard, H.-D. Automated Karl Fischer titration for liquid samples-Water determination in edible oils. Food Chem. 2008, 106, 1379-1384. [CrossRef]

39. Schmitt, K.; Isengard, H.-D. Karl Fischer titration. A method for determining the true water content of cereals. Fresenius' J. Anal. Chem. 1998, 360, 465-469. [CrossRef]

40. Merkh, G.; Pfaff, R.; Isengard, H.-D. Capabilities of automated Karl Fischer titration combined with gas extraction for water determination in selected dairy products. Food Chem. 2012, 132, 1736-1740. [CrossRef]

41. Isengard, H.-D.; Kerwin, H. Proposal of a new reference method for determining water content in butter oil. Food Chem. 2003, 82, 117-119. [CrossRef]

42. Tomassetti, M.; Campanella, L.; Aureli, T. Thermogravimetric analysis of some spices and commercial food products. Comparison with other analytical methods for moisture content determination (Part 3). Thermochim. Acta 1989, 143, 15-26. [CrossRef]

43. Isengard, H.-D.; Haschka, E.; Merkh, G. Development of a method for water determination in lactose. Food Chem. 2012, 132, 1660-1663. [CrossRef]

44. Kestens, V.; Conneely, P.; Bernreuther, A. Vaporisation coulometric Karl Fischer titration: A perfect tool for water content determination of difficult matrix reference materials. Food Chem. 2008, 106, 1454-1459. [CrossRef]

45. Rückold, S.; Grobecker, K.H.; Isengard, H.-D. The effects of drying on biological matrices and the consequences for reference materials. Food Control. 2001, 12, 401-407. [CrossRef]

46. Kestens, V.; Charoud-Got, J.; Bau', A.; Bernreuther, A.; Emteborg, H. Online measurement of water content in candidate reference materials by acousto-optical tuneable filter near-infrared spectrometry (AOTF-NIR) using pork meat calibrants controlled by Karl Fischer titration. Food Chem. 2008, 106, 1359-1365. [CrossRef]

47. Isengard, H.-D.; Färber, J.-M. 'Hidden parameters' of infrared drying for determining low water contents in instant powders. Talanta 1999, 50, 239-246. [CrossRef]

48. Belitz, H.-D.; Grosch, W.; Schieberle, P. Food Chemistry; Springer: Berlin, Germany, 2009; pp. 670-745. [CrossRef]

49. Bhatt, C.M.; Nagaraju, J. Studies on electrical properties of wheat bread as a function of moisture content during storage. Sens. Instrum. Food Qual. Saf. 2010, 4, 61-66. [CrossRef]

50. Isengard, H.-D.; Heinze, P. Determination of total water and surface water in sugars. Food Chem. 2003, 82, 169-172. [CrossRef]

51. Ureta, M.M.; Diascorn, Y.; Cambert, M.; Flick, D.; Salvadori, V.O.; Lucas, T. Water transport during bread baking: Impact of the baking temperature and the baking time. Food Sci. Technol. Int. 2018, 25, $187-197$. [CrossRef]

52. Hădărugă, D.I.; Birău (Mitroi), C.L.; Gruia, A.T.; Păunescu, V.; Bandur, G.N.; Hădărugă, N.G. Moisture evaluation of $\beta$-cyclodextrin/fish oils complexes by thermal analyses: A data review on common barbel (Barbus barbus L.), Pontic shad (Alosa immaculata Bennett), European wels catfish (Silurus glanis L.), and common bleak (Alburnus alburnus L.) living in Danube river. Food Chem. 2017, 236, 49-58. [CrossRef]

53. Hădărugă, N.G.; Bandur, G.N.; David, I.; Hădărugă, D.I. A review on thermal analyses of cyclodextrins and cyclodextrin complexes. Environ. Chem. Lett. 2019, 17, 349-373. [CrossRef]

54. Hădărugă, N.G.; Szakal, R.N.; Chirilă, C.A.; Lukinich-Gruia, A.T.; Păunescu, V.; Muntean, C.; Rusu, G.; Bujancă, G.; Hădărugă, D.I. Complexation of Danube common nase (Chondrostoma nasus L.) oil by $\beta$-cyclodextrin and 2-hydroxypropyl- $\beta$-cyclodextrin. Food Chem. 2020, 303, 125419. [CrossRef] [PubMed]

55. Curti, E.; Carini, E.; Tribuzio, G.; Vittadini, E. Effect of bran on bread staling: Physico-chemical characterization and molecular mobility. J. Cereal Sci. 2015, 65, 25-30. [CrossRef]

56. Curti, E.; Carini, E.; Diantom, A.; Vittadini, E. The use of potato fibre to improve bread physico-chemical properties during storage. Food Chem. 2016, 195, 64-70. [CrossRef]

57. Chiavaro, E.; Vittadini, E.; Musci, M.; Bianchi, F.; Curti, E. Shelf-life stability of artisanally and industrially produced durum wheat sourdough bread ("Altamura bread"). LWT Food Sci. Technol. 2008, 41, 58-70. [CrossRef]

58. Marzec, A.; Lewicki, P.P. Antiplasticization of cereal-based products by water. Part I. Extruded flat bread. J. Food Eng. 2006, 73, 1-8. [CrossRef] 
59. Kobus-Cisowska, J.; Szymanowska-Powałowska, D.; Szymandera-Buszka, K.; Rezler, R.; Jarzębski, M.; Szczepaniak, O.; Marciniak, G.; Jędrusek-Golińska, A.; Kobus-Moryson, M. Effect of fortification with calcium from eggshells on bioavailability, quality, and rheological characteristics of traditional Polish bread spread. J. Dairy Sci. 2020, 103, 6918-6929. [CrossRef]

60. Primo-Martín, C.; de Beukelaer, H.; Hamer, R.J.; Van Vliet, T. Fracture behaviour of bread crust: Effect of ingredient modification. J. Cereal Sci. 2008, 48, 604-612. [CrossRef]

61. Purlis, E.; Salvadori, V.O. Modelling the browning of bread during baking. Food Res. Int. 2009, 42, 865-870. [CrossRef]

62. Primo-Martín, C.; van de Pijpekamp, A.; van Vliet, T.; de Jongh, H.H.J.; Plijter, J.J.; Hamer, R.J. The role of the gluten network in the crispness of bread crust. J. Cereal Sci. 2006, 43, 342-352. [CrossRef]

63. Pico, J.; Reguilón, M.P.; Bernal, J.; Gómez, M. Effect of rice, pea, egg white and whey proteins on crust quality of rice flour-corn starch based gluten-free breads. J. Cereal Sci. 2019, 86, 92-101. [CrossRef]

64. Lind, I.; Rask, C. Sorption isotherms of mixed minced meat, dough, and bread crust. J. Food Eng. 1991, 14, 303-315. [CrossRef]

65. Wolter, A.; Hager, A.-S.; Zannini, E.; Czerny, M.; Arendt, E.K. Influence of dextran-producing Weissella cibaria on baking properties and sensory profile of gluten-free and wheat breads. Int. J. Food Microbiol. 2014, 172, 83-91. [CrossRef] [PubMed]

66. Grünke, S.; Wünsch, G. Kinetics and stoichiometry in the Karl Fischer solution. Fresenius' J. Anal. Chem. 2000, 368, 139-147.

67. Yap, W.T.; Cummings, A.L.; Margolis, S.A.; Schaffer, R. Estimation of water content by kinetic method in Karl Fischer titration. Anal. Chem. 1979, 51, 1595-1596. [CrossRef]

68. Hădărugă, D.I.; Hădărugă, N.G.; Bandur, G.N.; Isengard, H.-D. Water content of flavonoid/cyclodextrin nanoparticles: Relationship with the structural descriptors of biologically active compounds. Food Chem. 2012, 132, 1651-1659. [CrossRef]

69. Hădărugă, N.G.; Hădărugă, D.I.; Isengard,H.-D. "Surface water" and "strong-bonded water" in cyclodextrins: A Karl Fischer titration approach. J. Incl. Phenom. Macrocycl. Chem. 2013, 75, 297-302. [CrossRef]

70. Ünlüsayin, M.; Hădărugă, N.G.; Rusu, G.; Gruia, A.T.; Păunescu, V.; Hădărugă, D.I. Nano-encapsulation competitiveness of omega-3 fatty acids and correlations of thermal analysis and Karl Fischer water titration for European anchovy (Engraulis encrasicolus L.) oil/ß-cyclodextrin complexes. LWT Food Sci. Technol. 2016, $68,135-144$. [CrossRef] 